\title{
Role of Dopants on Ceria-based Anodes for IT-SOFCs Powered by Hydrocarbon Fuels
}

\author{
Araceli Fuerte*, Rita Ximena Valenzuela, María José Escudero \\ Energy Department, Centre for Energy, Environment and Technology (CIEMAT), Spain
}

Copyright@ 2017 by authors, all rights reserved. Authors agree that this article remains permanently open access under the terms of the Creative Commons Attribution License 4.0 International License

\begin{abstract}
The direct use of hydrocarbon or hydrocarbon-derived fuels to generate electrical power has the potential to accelerate substantially the use of fuel cells in transportation and distributed-power applications. Most fuel-cell research has involved the use of hydrogen as the fuel, although the practical generation and storage of hydrogen remains an important technological hurdle. Although hydrocarbon fuels have been successfully oxidised or reformed electrochemically, the susceptibility to carbon formation or poor power densities has prevented the application of these fuels in practical applications. In this manuscript, the effect of different dopants on the properties of $\mathrm{Cu}$-ceria based anodes for IT-SOFCs powered by hydrocarbon fuels has been explored. Four dopants atoms (Co, $\mathrm{Ca}, \mathrm{Ag}$ and $\mathrm{Rh}$ ) with different properties and concomitant varied effects on properties of the final material are studied. They have been selected in order to improve the electrical and textural properties of anode material as well as the catalytic activity for hydrocarbon oxidation. Results revealed a strong dependence of the final properties of the anode formulation and mechanism involved in the electro-oxidation of the different fuels. Different doping successfully improves the behaviour of anode material for IT-SOFCs powered by hydrocarbon fuels and reasonable power densities can be achieved.
\end{abstract}

Keywords Ceria Based Anodes, SOFC, Dopants, Alternative Fuels

\section{Introduction}

Solid oxide fuel cells (SOFCs) have attracted much attention because of their distinguished advantages over other types of fuel cells. High operating temperatures enable them to use a wide variety of fuels including hydrogen, natural gas and biogas [1]. However, one of the major challenges for the direct use of hydrocarbon fuels is the poisoning of common Ni-based anodes by coke formation [2] and impurities such as sulfur compounds, halides, siloxanes, etc. [3] in readily available hydrocarbon fuels. Typically, prereforming and/or desulfurization units are needed to reform these feedstocks; however, both installations reduce the potential for applying hydrogen/fuel cells technologies. Furthermore, research on SOFC technology in recent years has been focused on lowering the operating temperature, primarily driven by the cost and durability of components. Unfortunately, operation at lower temperature creates problems associated with the increase in the electrolyte resistance and the electrode polarization as well as decreasing rate of electrocatalytic reactions. Therefore, it is necessary to continuously search for novel anode materials having superior electrocatalytic activity in the intermediate temperature range and less prone to deactivation.

Different strategies have been proposed to improve the properties of ceria based anodes, focused on enhancing their conductivity and activity, especially for hydrocarbons oxidation.

For instance, it is well known that one method for avoiding the anode deactivation for carbon deposition is to replace nickel for another electrical conductor, such as copper, but it is still constantly reported that even traces of sulfur in the fuel causes a dramatic decrease in the SOFC performance. Copper is relatively inert for carbon-deposition reactions but is not a good catalyst for $\mathrm{C}-\mathrm{H}$ bond scission, making it necessary to add an additional catalytic component to oxidize hydrocarbon fuels, for example, cerium oxide. In addition, ceria is used as a sulfur-removal material as well as to have good hydrocarbon oxidation activity. Thus, $\mathrm{Cu}$-ceria anodes compared to the standard composites could be an attractive solution [4]. On the other hand, the substitution of a lower-valent metal ion for cerium (e.g., $\mathrm{Gd}^{3+}, \mathrm{Tb}^{3+}$ ) increasing the oxygen vacancy concentration and concomitant oxide ion conductivity [5], the formation of alloys (e.g., $\mathrm{Cu}-\mathrm{Ni}$ ) [6] or bimetallic systems [7] that enhance anode performance. It is noteworthy to mention that $\mathrm{Gd}-, \mathrm{Tb}-$ and Sm-doping of ceria increases the oxide ion conductivity making these materials promising candidates for SOFC operating at low temperatures (773-973 K). However, from the viewpoint of material expense, both $\mathrm{Gd}, \mathrm{Tb}$ and $\mathrm{Sm}$ are very costly. Hence there is an increasing interest to identify 
and develop new ceria-based oxides using cost-effective dopants for technological applications.

In this context, the present work explores the role of different dopants on ceria-based anodes for IT-SOFCs powered by hydrocarbon fuels. Several cations, $\mathrm{Co}, \mathrm{Ca}, \mathrm{Ag}$ and $\mathrm{Rh}$, have been selected to dope the base material, copper-doped ceria (hereafter named $\mathrm{Cu}-\mathrm{Ce}$ ), in order to improve its properties in this sense. It is expected that doping improves in several aspects: increase the oxide ion conductivity [8], change its catalytic activity for methane oxidation [9], smooth the progress of the sintering process [10] and improve it poison tolerance.

The primary purpose of this work is the synthesis and characterization at the structural level of these new materials as well as to test the performance and stability for the direct utilisation of hydrocarbon fuels. In the same sense, besides the electrical properties also thermal and chemical compatibility of this system with electrolyte material are analyzed. Catalytic activity test, sulfur tolerance tests and single cell operation with $\mathrm{H}_{2} \mathrm{~S}$-containing fuels have been also carried out. Anode properties of these materials are comparative analyse and discuss as a function of cation dopant and operational conditions.

\section{Materials and Methods}

\subsection{Preparation and Characterization of Anode Material}

CuM-codoped ceria $(\mathrm{M}=\mathrm{Co}, \mathrm{Ca}, \mathrm{Ag}, \mathrm{Rh})$ were prepared by precipitation within a reverse microemulsion and calcined in air at $1023 \mathrm{~K}$, details of the preparation method can be found elsewhere [11]. Elemental composition was analyzed via inductively coupled plasma-atomic emission spectroscopy (ICP-AES), after a selective chemical attack of samples by various media, such as $\mathrm{NaOH}$ and concentrated acids. XRD patterns were recorded at room temperature using a step scan procedure $\left(0.04^{\circ} / 2 \theta\right.$ step, time per step 2 s) in the $2 \theta$ range $20-80^{\circ}$ on a Philips X'Pert-MPD diffractometer equipped with a crystal monochromator employing $\mathrm{Cu}$ Ka radiation $(\lambda=1.5406 \AA)$. $\mathrm{X}$-ray photoelectron spectra (XPS) were recorded with a Perkin-Elmer PHI 5400 spectrometer equipped with $\mathrm{Mg} \mathrm{K \alpha}$ excitation source $(\mathrm{h} v=1253.60 \mathrm{eV})$ and a beam size of 1 $\mathrm{mm}$ diameter. Raman data were acquired using a Renishaw dispersive system 1000, equipped with a single monochromator, a holographic notch filter, and a cooled TCD. Morphology was investigated by scanning electron microscopy (SEM) and energy-dispersive X-ray analysis (EDS) a Hitachi-S-2500 microscope. Electrical conductivity was measured using electrochemical impedance spectroscopy, by the two-probe method with an Autolab Galvanostat/Potentiostat PGSTAT30 equipment with a frequency response analyzer. Frequencies were varied from 1 to $10 \mathrm{MHz}$ with $5 \mathrm{mV}$ amplitude. Measurements were carried out from 573 to $1023 \mathrm{~K}$ in air.
Thermal expansion coefficient (TEC) was measured on an alumina dilatometer, Linseis L75/1550, from room temperature to $973 \mathrm{~K}$, with a heating rate of $5 \mathrm{~K} \mathrm{~min}^{-1}$ and a $2 \mathrm{~h}$ dwell time at maximum temperature, under air and reducing atmosphere $\left(10 \% \quad \mathrm{H}_{2} / \mathrm{N}_{2}\right)$. For chemical compatibility test, the equal amount of anode material and electrolyte were thoroughly ground in an agate mortar and put into a quartz reactor. The mixture was fired in pure hydrogen for $50 \mathrm{~h}$ at $1023 \mathrm{~K}$. After completion, XRD partners were recorded under conditions described before.

Catalytic activity measurements were performed in a tubular quartz reactor operating at atmospheric pressure using $500 \mathrm{mg}$ of catalyst (0.25-0.42 mesh) packed on a bed of quartz wool. The catalyst was diluted with $\mathrm{SiC}(1 / 3 \mathrm{v} / \mathrm{v})$ to avoid undesired hot spots and to minimise temperature gradients in the catalytic bed. Reactants and products were analyzed on-line by gas chromatography. The activity tests were carried out in the temperature range of $673-1023 \mathrm{~K}$. Blank test, with reactor filled only by $\mathrm{SiC}$, showed that the reaction was negligible below $1023 \mathrm{~K}$. Sulfur tolerance tests were performed in a tubular quartz reactor using $0.2 \mathrm{~g}$ of anode material packed on a bed of quartz wool and employing $50 \mathrm{ml} \cdot \mathrm{min}^{-1}$ of $\mathrm{H}_{2} \mathrm{~S}$-containing dry and humidified $\mathrm{H}_{2}\left(500 \mathrm{ppm} \mathrm{H}_{2} \mathrm{~S}\right)$. The sample was heated up to $1023 \mathrm{~K}$ at a rate of $2 \mathrm{~K} \cdot \mathrm{min}^{-1}$ and held for $50 \mathrm{~h}$ under the reactant mixture. Structural changes taking place in the system after sulfur exposure were analyzed by XRD, Raman and XPS.

\subsection{Single Cell Fabrication and Test}

The single cells were fabricated as follow: electrolyte powders were used to form a disc-shaped dense electrolyte by applying uniaxial pressure. After sintering at $1675 \mathrm{~K}$ for $15 \mathrm{~h}$ the thickness of the dense electrolyte layer was about $290 \mu \mathrm{m}$. An electrolyte porous layer (»100 mm thick) was deposited onto the dense electrolyte by tape-casting method, using polymethyl methacrylate and decoflux-DW41 as pore former and binder respectively, then calcined at $1475 \mathrm{~K}$. The cathode material (LSM cathode paste) was applied onto the dense side of the wafer and calcined at $1273 \mathrm{~K}$. Anode powders was mixed with the desired amount of binder, applied onto the electrolyte porous layer by screen-printing and calcined at $1023 \mathrm{~K}$. Platinum and gold, pastes and wires, were used as current collector for cathode and anode, respectively. It should be noticed that noble metals are chosen as current collector because of they are reasonably inert and excellent electrical conductors under SOFC operation conditions. However, platinum catalyzes the hydrocarbon oxidation and for this reason, it cannot be used as anodic current collector when hydrocarbon fuels are used. The platinum-catalyzed oxidation of hydrocarbons could interfere and disguise the successful fuel conversion catalyzed by anode material. When SOFC is operated with hydrogen platinum can be chosen as both current collectors, anodic and cathodic. Finally, the cell was attached to an alumina tube with a ceramic seal (Ceramabond 552) and 
placed into a furnace. The active area was $0.28 \mathrm{~cm}^{2}$.

Fuel was supplied to the anode, at a total flow rate of 50 $\mathrm{ml} \cdot \mathrm{min}^{-1}$, after passing through a saturator at room temperature to adjust the gas humidity at $3 \% \mathrm{H}_{2} \mathrm{O}$. Hydrogen sulfide (volumetric ppm) was added to the fuel gas in order to evaluate the anode sulfur tolerance. Long periods of time were used for $\mathrm{H}_{2} \mathrm{~S}$ cell exposures (1-5 h) and at least $1 \mathrm{~h}$ for recovering in order to reach a steady power output. The cathode was open to air. Following the protocol for start-up and cell stabilization, operating temperature $(1023 \mathrm{~K})$ was achieved at the rate of $1 \mathrm{~K} \cdot \mathrm{min}^{-1}$ under humidified hydrogen. Anode was reduced in situ for $24 \mathrm{~h}$. Cell performance was evaluated under galvanostatic control at the relatively low operating temperature of $1023 \mathrm{~K}$. For electrode activation, the cell was operating under humidified hydrogen at a constant current density for $48 \mathrm{~h}$. Voltage as a function of time and fuel composition, at constant current density and temperature, was measured for evaluating the endurance of the single cell. Before and after each modification in fuel composition, or current density, current-voltage (I-V) curves and impedance measurements were collected using an Autolab system (PGSTAT30 and FRA2 module, Eco Chemie). The impedance of cell was recorded at the open circuit in a galvanostatic mode with a frequency range of 0.1 $\mathrm{Hz}$ to $1 \mathrm{MHz}$ and an excitation signal of $5 \mathrm{~mA}$.

\section{Results}

Microemulsion preparation method was used as it facilitates, as much as possible, the homogeneity of chemical composition at a nanoscale level as well as the production of particles with a narrow size distribution. This method is able to obtain mixed oxides with particle size ranging from 15 to $30 \mathrm{~nm}$. $\mathrm{Rh}$ was deposited on $\mathrm{Cu}-\mathrm{CaCe}$ oxide using the incipient wetness method. In Table 1, main characteristics of these materials are reported.

Nominal cation amount employed was close (within experimental error) to experimental contents determined by ICP-AES chemical analysis EDS.

After calcination in air all samples are mainly constituted by the fluorite phase of the mixed oxide $\mathrm{M}_{\mathrm{x}} \mathrm{Cu}_{\mathrm{y}} \mathrm{M} 2_{\mathrm{z}} \mathrm{Ce}_{1-\mathrm{x}-\mathrm{y}-\mathrm{z}} \mathrm{O}_{2-\delta}(\mathrm{M} 1=\mathrm{Co}, \mathrm{Ag}, \mathrm{Rh} ; \mathrm{M} 2=\mathrm{Ca})$ and additional phases of the corresponding metal oxides $(\mathrm{CuO}$, $\mathrm{Co}_{2} \mathrm{O}_{3}, \mathrm{Rh}_{2} \mathrm{O}_{3}$ ). Note that in the case of $\mathrm{Ag} / \mathrm{Cu}-\mathrm{CaCe}$ metallic silver is detected instead of silver oxide due to the temperature of calcination [11]. The study of the variation in lattice parameter with the doping of ceria reveals that the insertion of $\mathrm{Cu}^{2+}$ ion in substitutional positions of the fluorite structure promotes a decrease in the lattice parameter [12], while the insertion of calcium promotes a slight increase in it. These variations are in concordance with the different ionic radii of dopants and confirm their successful introduction into the fluorite structure to form a solid solution. When three different dopants are incorporated into ceria composition the variation in lattice parameter $(<0.015 \mathrm{~nm})$ is determined by the different ionic radius of cations as well as the oxygen vacancies generated to ensure the electrical neutrality. Notice that part of metal ions exists at the anode surface as metal oxides or metallic silver. Under working anode conditions, high temperature and reducing atmosphere, metal oxides are reduced to their metallic state $\left(\mathrm{Cu}^{0}, \mathrm{Co}^{0}, \mathrm{Rh}^{0}\right)$ and coexists with the fluorite phase for the mixed oxide (Figure 1).

Table 1. Main characterization results of $\mathrm{Cu}-\mathrm{M}$ codoped ceria anodes

\begin{tabular}{|c|c|c|c|c|c|}
\hline \multirow{2}{*}{ Sample } & \multirow{2}{*}{$\mathrm{M}$ atom content ${ }^{\mathrm{a}}$ (at.\%) } & \multirow{2}{*}{ Fluorite crystal size $\mathrm{e}^{\mathrm{b}}(\mathrm{nm})$} & \multicolumn{2}{|c|}{$\operatorname{TEC}\left(10^{-6} \mathrm{~K}^{-1}\right)$} & \multirow{2}{*}{$\sigma\left(\mathrm{S} \cdot \mathrm{cm}^{-1}\right)$} \\
\hline & & & Air & $\mathrm{H}_{2}$ & \\
\hline $\mathrm{Cu}-\mathrm{Ce}$ & $42(\mathrm{Cu})$ & 30.7 & 11.3 & 12.6 & 0.61 \\
\hline $\mathrm{Co} / \mathrm{Cu}-\mathrm{Ce}$ & $19 / 20(\mathrm{Co} / \mathrm{Cu})$ & 33.9 & 10.2 & 12.3 & 0.66 \\
\hline $\mathrm{Cu}-\mathrm{CaCe}$ & $37 / 11(\mathrm{Cu} / \mathrm{Ca})$ & 32.8 & 11.4 & 11.7 & 0.73 \\
\hline $\mathrm{Ag} / \mathrm{Cu}-\mathrm{CaCe}$ & $8 / 30 / 10(\mathrm{Ag} / \mathrm{Cu} / \mathrm{Ca})$ & 30.6 & 10.1 & 13.3 & 0.75 \\
\hline $\mathrm{Rh} / \mathrm{Cu}-\mathrm{CaCe}$ & $0.4 \mathrm{wt} / 38 / 10(\mathrm{Rh} / \mathrm{Cu} / \mathrm{Ca})$ & 29.7 & 11.4 & 13.3 & 1.68 \\
\hline
\end{tabular}

${ }^{a}$ Measured by ICP-AES and/or EDS; ${ }^{b}$ Measured by XRD-Scherrer equation; $\sigma=$ electrical conductivity 


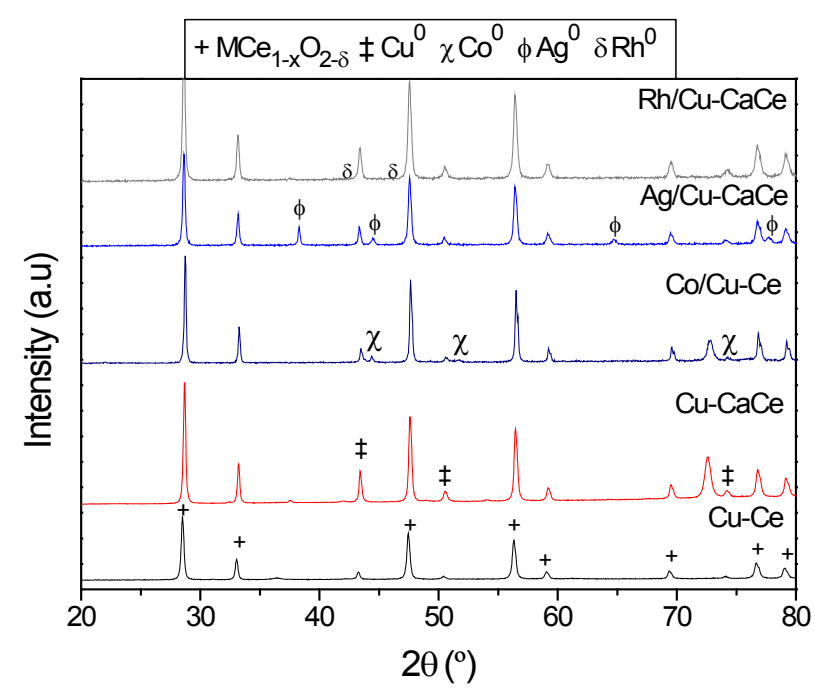

Figure 1. XRD patterns for reduced cerium mixed oxides $\left(10 \% \mathrm{H}_{2} / \mathrm{N}_{2}\right)$, $1023 \mathrm{~K}$

One characteristic that determines the validity or not for using a material in high-temperature fuel cells is the thermal expansion coefficient (TEC), which must be similar to the electrolyte in order to prevent the degradation of these cells in the heating and cooling processes. Thermal expansion of new materials was evaluated in both air and reducing atmosphere $\left(5 \% \mathrm{H}_{2} / \mathrm{N}_{2}\right)$. TEC values were estimated from the slope of the plot of the relative change in length vs. temperature from $473 \mathrm{~K}$ to $1023 \mathrm{~K}$. In air, sample experiments a linear expansion with a TECs close value to the common SOFC electrolyte material; values of $10.2 \cdot 10^{-6}-11.4 \cdot 10^{-6} \mathrm{~K}^{-1}$, depending on the sample (see Table 1 ), were obtained. However, under reducing conditions slope increases to $\approx 13 \cdot 10^{-6} \mathrm{~K}^{-1}$ and a nonlinear curve is obtained. Change of the slope, at approximately $873 \mathrm{~K}$, gives evidence of structural modifications associated with a modification of cell volume of the doped ceria, such as the formation of oxygen vacancies. Similar behavior has been observed for other related doped-cerium oxides [13]. The formation of oxygen vacancies at high temperature and reducing atmosphere is highly advantageous for the electrical conductivity of anode material based on the increased oxygen ion mobility that results in improved cell performance.

The chemical compatibility between electrode materials and the electrolyte is a prerequisite to any further cell testing. Indeed, the formation of reaction products at the electrode/electrolyte interface could be detrimental to the cell efficiency. The cationic interdiffusion has to be limited in order to prevent the degradation of electrode and electrolyte materials properties. In this sense, reactivity study was carried out to assess the interaction between the anodic formulations and common SOFC electrolytes (YSZ, SDC and LSGM). The XRD study clearly allows to discard any chemical reaction between electrode and electrolyte; only diffraction peaks for fluorite and metal phases were seen. No new additional phases in the boundary between electrode/electrolyte neither changes were observed. As an example, compatibility tests carried out between the $\mathrm{Cu}-\mathrm{CaCe}$ anode material and three common SOFC electrolytes (8YSZ, SDC and LSGM) are shown (Figure 2). Note that diffraction peaks for SDC electrolyte overlap with those for $\mathrm{Cu}-\mathrm{CaCe}$ anode.

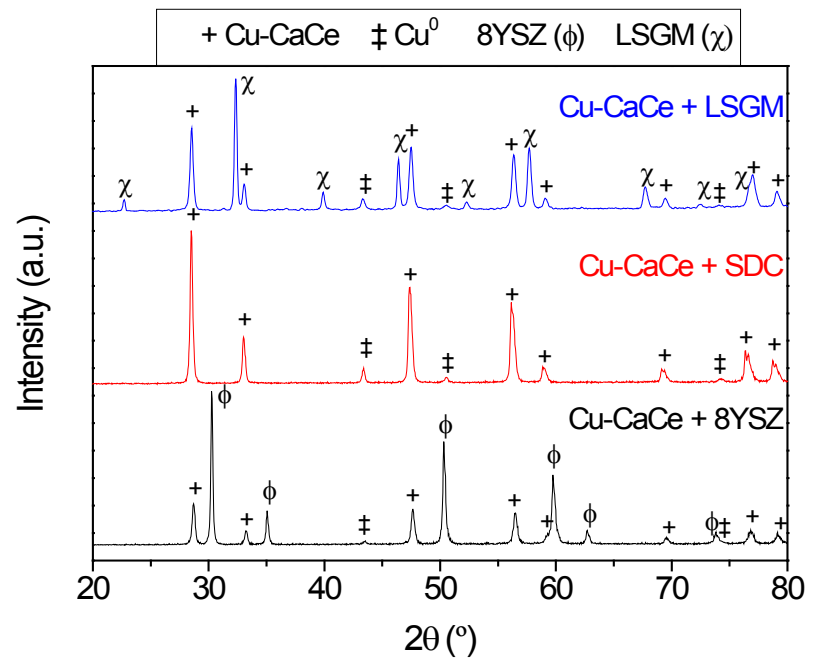

Figure 2. Compatibility tests between $\mathrm{Cu}-\mathrm{CaCe}$ and common SOFC electrolytes

Concerning electrical conductivity of sintered anode material, it was measured under reducing atmosphere from $773 \mathrm{~K}$ to $1023 \mathrm{~K}$ (Table 1 ), in $10 \% \mathrm{H}_{2}-90 \% \mathrm{~N}_{2}$ formingas, by the conventional DC four-probe method. The Arrhenius plot obtained (not shown) revealed semiconductor behavior, electrical conductivity increases with increasing temperature, with the calculated activation energy of $1 \mathrm{eV}$ approximately. Samples display conductivity values between $0.6-1.7 \mathrm{~S} \cdot \mathrm{cm}^{-1}\left(1023 \mathrm{~K}, \mathrm{pO}_{2}=10^{-23} \mathrm{~atm}\right)$, being $\mathrm{Cu}-\mathrm{Ce}$ sample with lower electrical conductivity under the same measurement conditions. $\mathrm{CuCa}$-doped ceria has higher conductivity in comparison with the $\mathrm{Ca}$-free analogous sample. This could be due to higher oxide ion conductivity and concomitant total electrical conductivity induces for calcium incorporation to the lattice of cerium oxide.

Finally, the evaluation of these materials on single cell configuration has allowed identifying the improved properties of each material, in comparison con base material $\mathrm{Cu}-\mathrm{Ce}$, due to the incorporated dopant. Single cell fabrication yields a dense electrolyte layer $(\approx 250-300 \mu \mathrm{m}$ thickness, 8YSZ, SDC or LSGM) that appears sandwiched between the porous anode and cathode layer. No cracks or pinholes were observed in the electrolyte and the electrode layers are intimately connected to the electrolyte. All single cells were long-term operating (800-1000 h) at $1023 \mathrm{~K}$ under humidified $\mathrm{H}_{2}, \mathrm{CH}_{4}$, simulated biogas mixtures and $\mathrm{H}_{2} \mathrm{~S}$-containing fuels. Current demand was fixed to operate the cell under maximum power density and maximum power conditions.

Due to the large amount of data and the limited extension of this paper, a brief resume of better results for each dopant 
are described below. Results were supported by catalytic activity tests and sulfur tolerance tests (10-1000 ppm $\mathrm{H}_{2} \mathrm{~S}$ ) carried out using several fuel compositions and operational conditions (dry and humidified atmospheres). The microstructural post-analysis of single cells after long term test was carried out by SEM-EDS. Although only the analysis of one of the single cells is reported below as an example, note that similar results were obtained for the others single cells and similar conclusions can be extracted from these analyses.

\subsection{Effect of Ceria-doping with Cobalt}

In order to improve the catalytic activity of copper, in anode materials for hydrocarbon-directly fuelled SOFC, several approaches have been proposed. $\mathrm{Cu}-\mathrm{Ni}$ alloys demonstrated that carbon formation was strongly suppressed compared to nickel anodes [14] but their stability was limited in the presence of hydrocarbon. Ni and Co have similar catalytic properties for hydrocarbon reactions; but the $\mathrm{Cu}-\mathrm{Ni}$ and $\mathrm{Cu}-\mathrm{Co}$ systems provide an interesting contrast in that $\mathrm{Cu}$ and $\mathrm{Ni}$ are completely miscible while $\mathrm{Cu}$ and $\mathrm{Co}$ are not, being of great interest for SOFC anode development [15]. $\mathrm{Co} / \mathrm{Cu}-\mathrm{Ce}$ (metal load $=40$ at. $\%, \mathrm{Co} / \mathrm{Cu}$ ratio $=1$ ) has been studied as anode material for SOFC running with hydrogen and methane [16] as well as $\mathrm{H}_{2}$ and simulated biogas, sulfur-free or $\mathrm{H}_{2} \mathrm{~S}$-containing fuels [17].

The bimetallic mixed oxide $\mathrm{Co} / \mathrm{Cu}-\mathrm{Ce}$ has demonstrated promising properties for its application as SOFC anode operating at relatively low temperature (1023 K). Maximum power density significantly increased with the incorporation of cobalt to the anode formulation (Figure 3), even in methane fuel. These results are in good concordance with catalytic activity results that demonstrated higher activity for methane oxidation of $\mathrm{Co} / \mathrm{Cu}-\mathrm{Ce}$ in comparison with $\mathrm{Cu}-\mathrm{Ce}$ anode (data not shown).

Polarisation resistance is reduced with the incorporation of cobalt into anode composition; this is ascribed to a favored charge transfer that increases the efficiency of the triple phase boundary (TPB) process [18].

Furthermore, $\mathrm{Co} / \mathrm{Cu}-\mathrm{Ce}$ exhibits high sulfur tolerance (up to $1000 \mathrm{ppm}_{2} \mathrm{~S}$ in fuel) and the capability to operate on hydrogen, methane and simulated biogas compositions [17]. Reliable and stable single cell performance was achieved over a long term period (740-900 h overall) without evidence for sulfur or carbon poisoning of anode material. The utilization of this anode material, catalytically active for the methane oxidation, allows combining the exothermicity of this reaction with the endothermic methane reforming improving the electrical efficiency of single cell running on biogas.
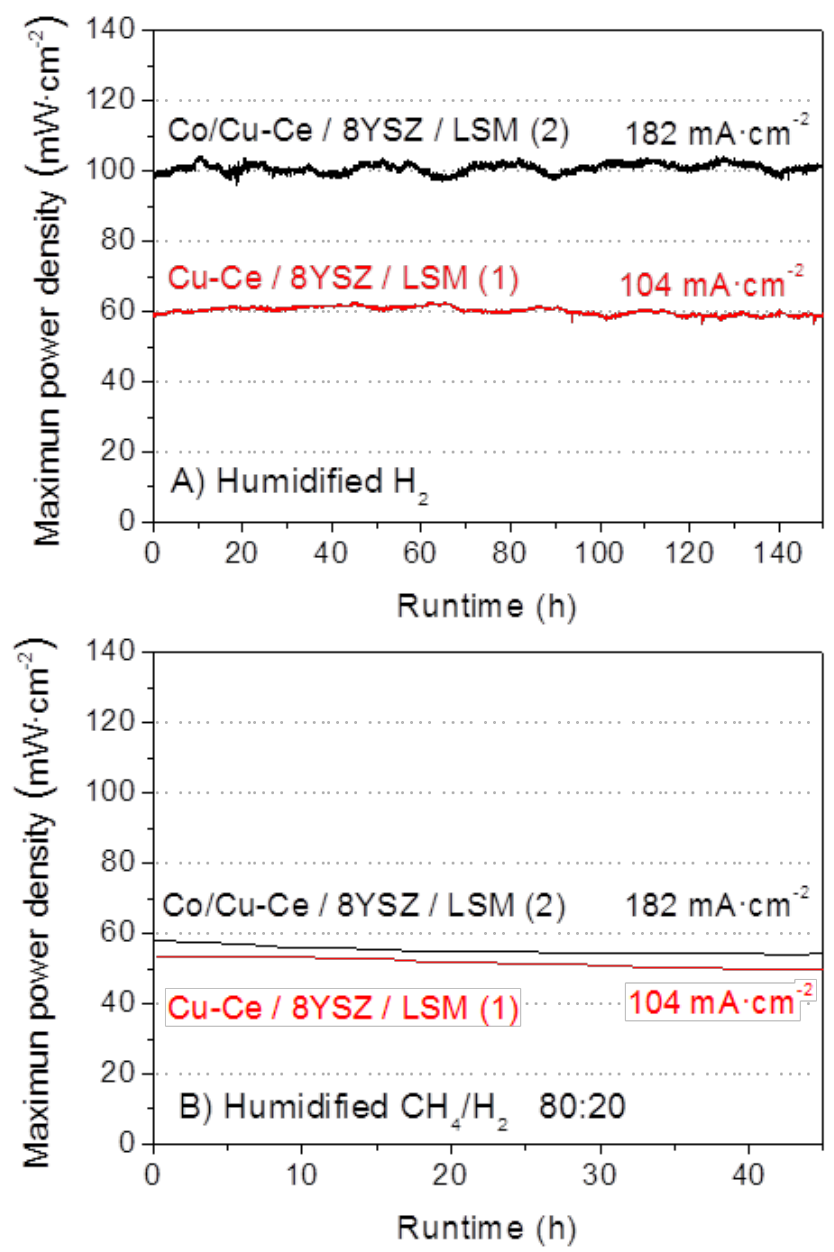

Figure 3. Maximum power density of single cells (1) and (2) as a function of time under humidified $\mathrm{H}_{2}$ (Part A) and $\mathrm{CH}_{4} / \mathrm{H}_{2}$ (Part B)

\subsection{Effect of Ceria-doping with Calcium}

It is noteworthy to mention that Gd-, Tb- and Sm-doping of ceria increases the oxide ion conductivity making these materials promising candidates for SOFC operating at low temperatures (773-973 K). However, from the viewpoint of material expense, both, $\mathrm{Gd}, \mathrm{Tb}$ and $\mathrm{Sm}$ are very costly. Hence there is an increasing interest to identify and develop new ceria-based oxides using cost-effective dopants for technological applications. In this sense, the use of an alkaline rare-earth (such as divalent cation $\mathrm{Ca}^{2+}$ ) is an interesting and much less expensive option [19].

Two similar single cells with $\mathrm{Cu}-\mathrm{Ce}$ and $\mathrm{Cu}-\mathrm{CaCe}$ anodes, based on SDC electrolyte and LSM cathode, were evaluated for $900 \mathrm{~h}$, under humidified hydrogen, methane or mixtures $\mathrm{H}_{2} / \mathrm{CH}_{4}$. I-V and I-P curves registered under different fuel composition are comparatively shown in Fig. 4 


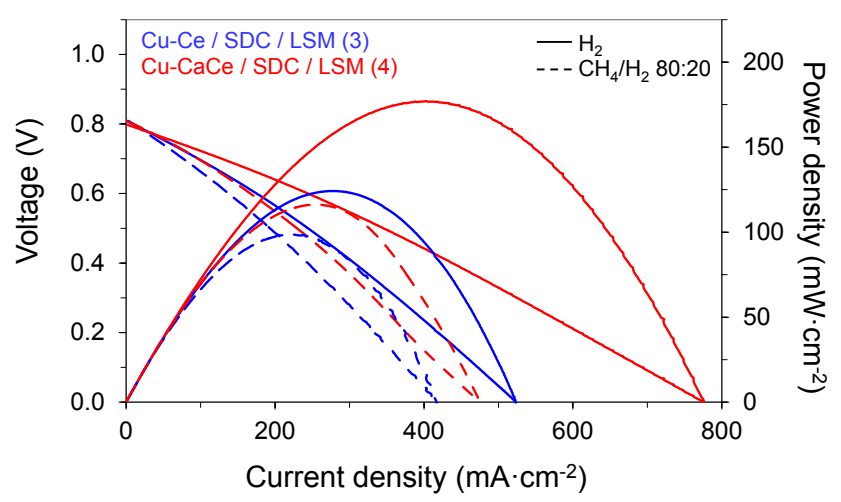

Figure 4. I-V and I-P curves for single cells (3) and (4) at $1023 \mathrm{~K}$ in different humidified fuels $\left(\mathrm{H}_{2}\right.$ : straight line, $\mathrm{CH}_{4} / \mathrm{H}_{2}$ : dashed line)

The open-circuit voltages (OCVs) at $1023 \mathrm{~K}$ and different fuels were close to $0.8 \mathrm{~V}$. These values are consistent with those reported for ceria-based cells in this temperature range. They are slightly lower than the values predicted by Nerst equation assuming different methane reactions in the anode at this temperature. We attribute that as resulting from the fact that oxidation of methane on surfaces may occur in multiple steps so that, the equilibrium is established between the methane and partial oxidation products. On the other hand, since the cell is being operated at very low $\mathrm{pO}_{2}$ that may cause the partial reduction of the ceria electrolyte and induces some mixed electronic-ionic conductivity, being this electronic conductivity the cause of low OCVs. No significant difference exists between OCV of both single cells.

The maximum power density in humidified hydrogen significantly increases, from 124 to $177 \mathrm{~mW} \cdot \mathrm{cm}^{-2}$, with the incorporation of calcium in the anode formulation (Figure 4). The partial replacement of hydrogen with methane $(80 \%)$ entails a worsening of single cell performance due to chemical limitations [16]. However, a reliable and stable performance was observed.

The characterization by impedance spectroscopy reveals an important decrease (44\%) of the total internal cell resistance with the use of anode $\mathrm{Cu}-\mathrm{CeCa}$. The ohmic resistance was similar for both cells $\left(0.5-0.7 \Omega \cdot \mathrm{cm}^{2}\right)$ but the polarisation resistance was reduced from 1.40 to 0.78 $\Omega \cdot \mathrm{cm}^{2}$ (values for $\mathrm{Cu}-\mathrm{Ce}$ and $\mathrm{Cu}-\mathrm{CaCe}$ respectively), giving evidence of the improved conductivity with the introduction of calcium into the ceria lattice.

Taking into account all the experiments carried out with these two anodes is possible to conclude that the properties of doped ceria improved in several aspects with the incorporation of calcium to the fluorite lattice. It improves the oxide ion conductivity, changes its catalytic activity for methane oxidation as well as to smooth the progress of the sintering process.

Additionally, it was observed that sulfur interaction is mitigated by the presence of calcium in the anode composition. These improved properties are shown too during biogas operation and under sulfur presence.

\subsection{Effect of Calcium/Ceria-doping with Silver}

Silver catalysts are considered for its excellent activity for selective oxidation processes. Some investigations have been focused on the incorporation of silver to the anode composition for hydrocarbon-fueled SOFC [20-22]. Thus, it has been included in the composition of $\mathrm{Cu}-\mathrm{CaCe}$ to sum the effect of calcium and silver in the final properties of this ceria-based anode. This material, $\mathrm{Ag} / \mathrm{Cu}-\mathrm{CaCe}$ has shown stable and reliable performance running on different fuels and in the presence of sulfur [23, 24]. In Fig. 5 maximum power density in different fuels are collected. Fuel compositions were as follow: $\mathrm{H}_{2}, \mathrm{H}_{2} / \mathrm{CH}_{4}(40: 60,20: 80$ and pure methane), simulated biogas mixtures $\left(\mathrm{CH}_{4} / \mathrm{CO}_{2} / \mathrm{H}_{2}\right.$ : 50/45/5, 60/35/5 and 70/25/5 for 50bio, 60bio and 70bio, respectively) and $\mathrm{H}_{2} \mathrm{~S}$-containing simulated biogas (50bioS, $60 \mathrm{bioS}$ and 70bioS) that incorporates $500 \mathrm{ppm}$ of $\mathrm{H}_{2} \mathrm{~S}$ to simulated biogas mixtures.

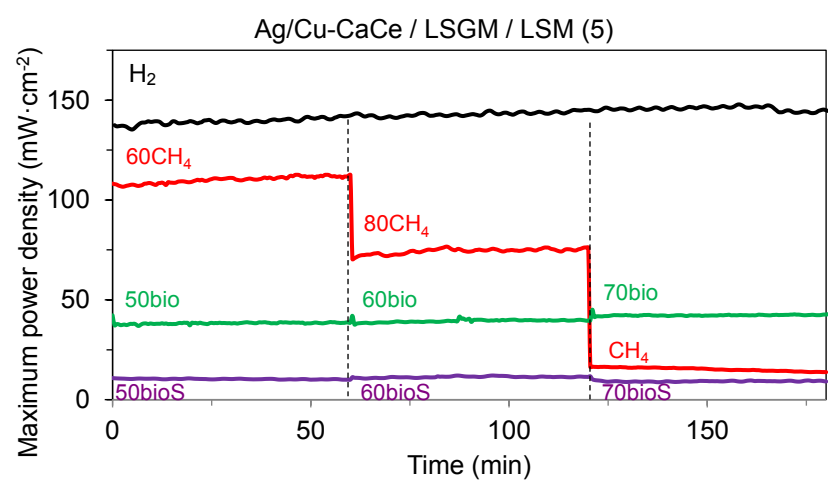

Figure 5. Maximum power density of $\mathrm{Ag} / \mathrm{Cu}-\mathrm{CaCe} / \mathrm{LSGM} / \mathrm{LSM}$ single cell (5) in different fuels as a function of time

Catalytic activity tests for direct oxidation of methane were carried out (Figure 6a). The process of methane oxidation on $\mathrm{Cu}-\mathrm{CaCe}$ and $\mathrm{Ag} / \mathrm{Cu}-\mathrm{CaCe}$ took place differently depending on temperature. Firstly, reaction started at $800 \mathrm{~K}$ with $\mathrm{Cu}-\mathrm{CaCe}$, whereas lower temperature is required to start the reaction in presence of $\mathrm{Ag} / \mathrm{Cu}-\mathrm{CaCe}$ $(700 \mathrm{~K}) . \mathrm{CH}_{4}$ consumption is limited by the $\mathrm{O}_{2}$ content in both cases. Note that the reaction products were different depending on the catalyst. In the case of $\mathrm{Cu}-\mathrm{CaCe}$ synthesis gas, $\mathrm{CO}$ and $\mathrm{H}_{2}$ was formed above $870 \mathrm{~K}$ and selectivity to $\mathrm{H}_{2}$ was very low. However, in the case of $\mathrm{Ag} / \mathrm{Cu}-\mathrm{CaCe}$ practically all oxygen was consumed by methane towards to $\mathrm{CO}_{2}$ and $\mathrm{H}_{2} \mathrm{O}$. Reactions are summarised below. These analyses indicate that, under experimental conditions, direct methane oxidation (1) is the primary reaction and contribution of partial oxidation (2) to the global process is very small for $\mathrm{Ag} / \mathrm{Cu}-\mathrm{CaCe}$ whereas it is the main reaction for $\mathrm{Cu}-\mathrm{CaCe}$. After 3-day stability test, carbon deposits were accumulated near the catalytic bed, suggesting that methane conversion proceeds to some degree via pyrolysis (3).

$$
\begin{gathered}
\mathrm{CH}_{4}+4 \mathrm{O}^{2-} \rightarrow \mathrm{CO}_{2}+2 \mathrm{H}_{2} \mathrm{O}+8 \mathrm{e}^{-} \\
\mathrm{CH}_{4}+\mathrm{O}^{2-} \rightarrow \mathrm{CO}+2 \mathrm{H}_{2}+8 \mathrm{e}^{-}
\end{gathered}
$$




$$
\mathrm{CH}_{4} \rightarrow \mathrm{C}+2 \mathrm{H}_{2}
$$

Fig. 6B corresponding to TPO results for both anode materials after the catalytic test. Different peaks of $\mathrm{CO}_{2}$ $(\mathrm{m} / \mathrm{z}=44)$ were observed around $750-950 \mathrm{~K}$ related to different carbon species. Some authors attributed the high-temperature peaks (higher than $900 \mathrm{~K}$ ) to refractory or inert coke, whereas a more reactive coke (lower than $900 \mathrm{~K}$ ) is probably associated with amorphous carbonaceous deposits [25]. The slight shift of the $\mathrm{CO}_{2}$ peak to higher temperatures $(\sim 900 \mathrm{~K})$, observed for $\mathrm{Cu}-\mathrm{CaCe}$ in comparison with those for $\mathrm{Ag} / \mathrm{Cu}-\mathrm{CaCe}$, was regarded to be inactive species difficult to remove and thus responsible for the anode deactivation. However, the carbonaceous species observed on $\mathrm{Ag} / \mathrm{Cu}-\mathrm{CaCe}$ surface $(>900 \mathrm{~K}$ ) do not have a negative effect and would be considered reversibly converted to $\mathrm{CO}$ by $\mathrm{CO}_{2}$ oxidation. Furthermore, the TPO profile of $\mathrm{Ag} / \mathrm{Cu}-\mathrm{CaCe}$ gave evidence of a lower level formation of carbonaceous species (Figure 6B).

The microstructural post-analysis of single cell (5) after long term test $(515 \mathrm{~h})$ was carried out by SEM-EDS. Fig. $7 \mathrm{a}-\mathrm{b}$ shows cross-sectional microstructures of the interlayers of anode/electrolyte and cathode/electrolyte. A dense layer LSGM electrolyte, $\sim 250 \mu \mathrm{m}$ thick, appears sandwiched between the porous anode and cathode layer. No cracks or pinholes are observed in the electrolyte layer and electrode layers (anode and cathode) are intimately connected to the electrolyte. A typical microstructure of the deposited anode film is shown; anode exhibits a porous structure with a homogeneous distribution of faceted grains with a grain size smaller than 3-4 $\mu \mathrm{m}$ and formation of some agglomerates. In addition, elements are homogeneously distributed in the anode, date corroborated by the elemental analysis done by EDS. The spatial distributions of the different elements were determined by EDS mapping over $\mathrm{Ag} / \mathrm{CuCaCe} / \mathrm{LSGM}$ and LSGM / LSM interfaces to evaluate their chemical reaction behavior after long operation time. Diffusion must occur prior to chemical reaction. Therefore, the diffusion process is the controlling factor for any chemical reaction to occur at the interface. According to the phase analysis, see Fig. 7, it is clear that any anode and cathode species do not diffuse to react with
LSGM, forming undesirable new electrochemically inactive phases. After operation cell maintains well-defined phase boundaries. For determining the components of the anode section and EDS analysis was performed (Fig. 7c). No sulfur species were detected on the anode surface (K $\alpha$ peak at $2.3 \mathrm{keV}$ ). However, the presence of characteristic K $\alpha$ peak of carbon at $0.28 \mathrm{keV}$ gives evidence of the formation of carbon deposits on the anode surface after cell operation. These results are in good agreement with those obtained with the XRD and TPO results reported previously.
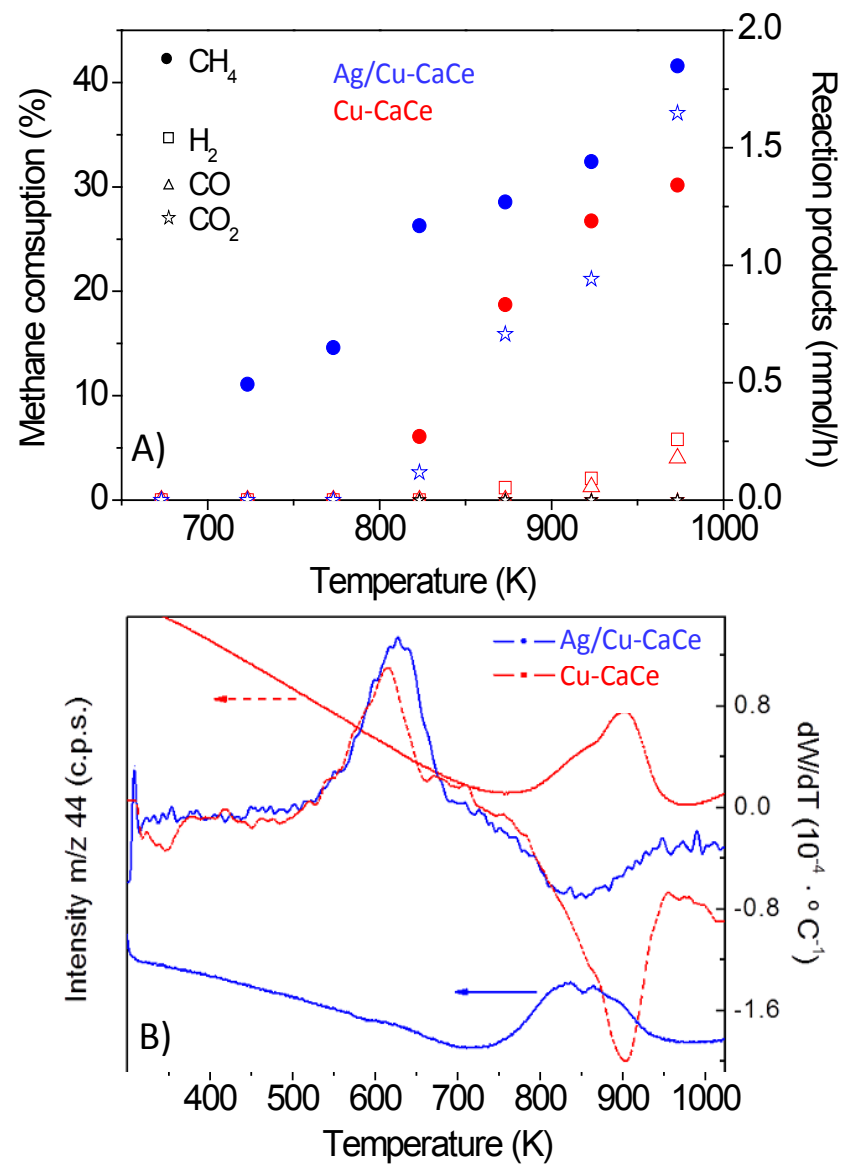

Figure 6. Part A: Catalytic active test: $\mathrm{CH}_{4} / \mathrm{O}_{2}$ 5:2 (Ar diluted), GHSV= $20000 \mathrm{~h}^{-1}$. Part B: TPO post-reaction $\left(10 \% \mathrm{O}_{2}\right)$ 

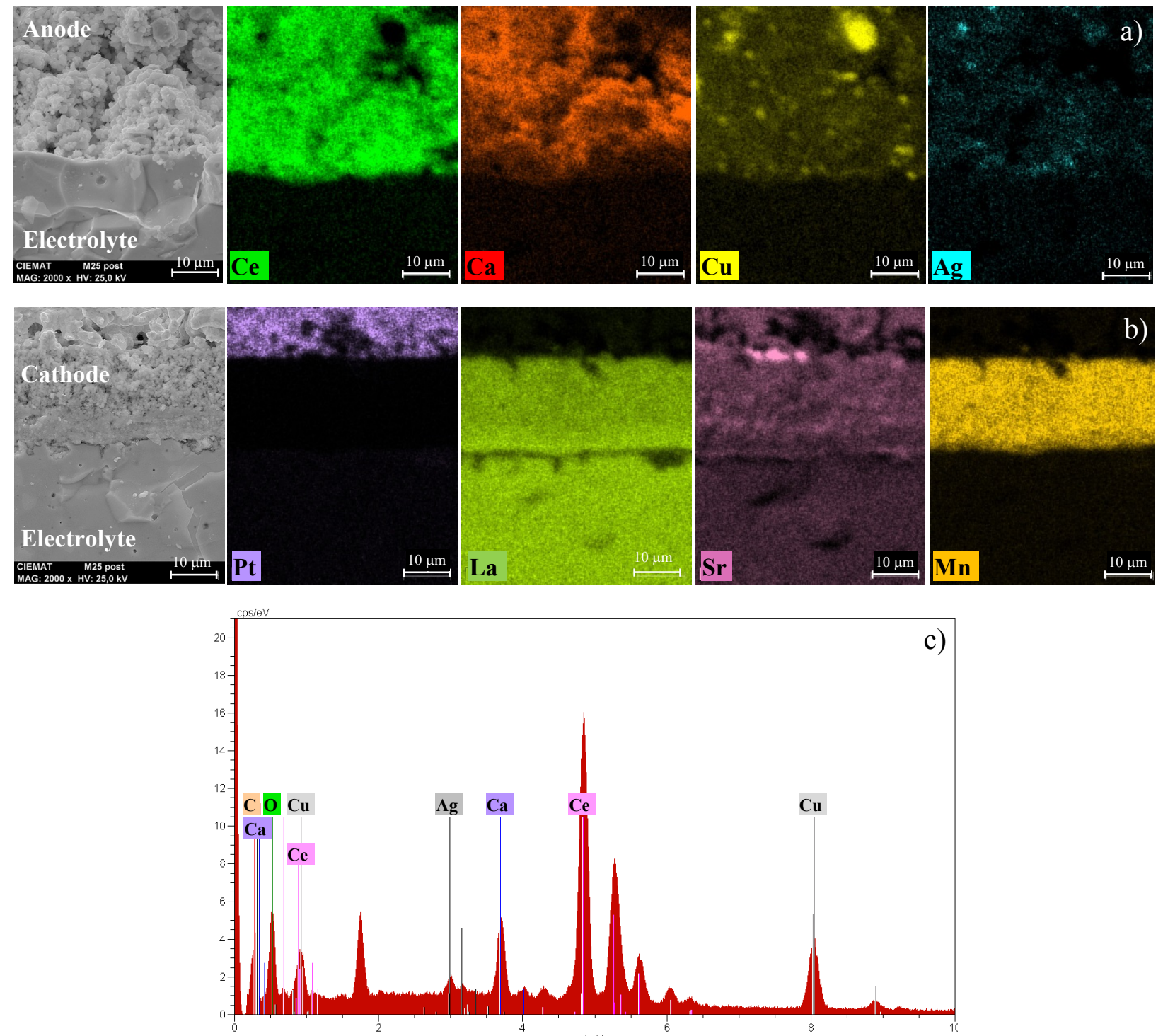

Figure 7. SEM micrographs and EDS mapping for the cross-sectional views of the $\mathrm{Ag} / \mathrm{Cu}-\mathrm{CaCe} / \mathrm{LSGM} / \mathrm{LSM}$ single cell (5) after $515 \mathrm{~h}$ test at $1023 \mathrm{~K}$ in different fuels $\left(\mathrm{H}_{2}, \mathrm{CH}_{4}, \mathrm{H}_{2} \mathrm{~S}\right.$ and simulated biogas). (a) Anode/electrolyte; (b) electrolyte/cathode and (c) EDS of anode section

\subsection{Effect of Calcium/Ceria-doping with Rhodium}

Although several improvements have been achieved, with the structural modifications of ceria, it is still needed to improve the anode activity for direct electrochemical oxidation of hydrocarbon fuels. Nobel metals have been widely used in many fields, especially in catalysis due to the quite high chemical stability and catalytic activity. In this context, small quantities ( 0.4 wt.\%) of rhodium were added to $\mathrm{Cu}-\mathrm{CaCe}$ in order to enhance the catalytic activity of the conductive layer. Fig. 7 shows the maximum power densities obtained with $\mathrm{Rh} / \mathrm{Cu}-\mathrm{CaCe}$ in a SDC-based single cell (single cell 6) running on different humidified fuels (3\% $\mathrm{H}_{2} \mathrm{O}$ ). Fuel compositions were as follow: $\mathrm{H}_{2}$, simulated biogas mixtures $\left(\mathrm{CH}_{4} / \mathrm{CO}_{2} / \mathrm{H}_{2}: 50 / 45 / 5,60 / 35 / 5\right.$ and $70 / 25 / 5$ for 50bio, 60bio and 70bio, respectively), $\mathrm{H}_{2} / \mathrm{H}_{2} \mathrm{~S}$ (500 ppm) and $\mathrm{H}_{2} \mathrm{~S}$-containing simulated biogas mixtures (50bioS, $60 \mathrm{bioS}$ and $70 \mathrm{bioS}$ ) that incorporate $500 \mathrm{ppm}$ of $\mathrm{H}_{2} \mathrm{~S}$ to simulated biogas mixtures.

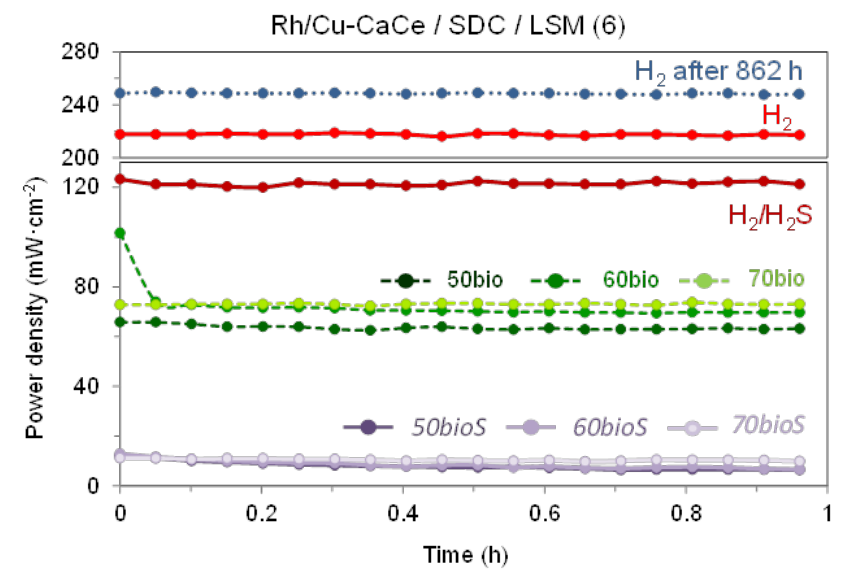

Figure 7. Maximum power density of the single cell $\mathrm{Rh} / \mathrm{Cu}-\mathrm{CaCe} / \mathrm{SDC}$ / LSM (6) in different fuels as a function of time 
Results give evidence of the successful improvement of anode properties with the rhodium incorporation in comparison and the capability of $\mathrm{Rh} / \mathrm{Cu}-\mathrm{CaCe}$ to operate in several fuels. Maximum power densities in different fuels are almost double the values obtained using the others $\mathrm{Cu}$-ceria based anodes studied in this work. Although maximum power density of the single cell was much lower running on simulated biogas or $\mathrm{H}_{2} \mathrm{~S}$-containing fuels comparing with hydrogen fuel, mainly due to chemical limitations and formation of carbon and sulfur species, it should be noted that voltage remained stable and cell performance was totally recovered after exposition to humidified hydrogen (Figure 7, blue dot plot). Even the maximum power density slightly increases after $860 \mathrm{~h}$ of operation using different fuels, values close to 250 $\mathrm{mW} \cdot \mathrm{cm}^{-2}$ were achieved. Post-operation analysis of single cell by SEM-EDS gave evidence of small carbon deposits on the anode surface that could contribute to the electrical conductivity of the anode.

Finally, it is important to mention that sulfur tolerance tests $\left(500 \mathrm{ppm}-\mathrm{H}_{2} \mathrm{~S} / \mathrm{H}_{2}\right)$ carried out with these new materials revealed a total sulfidation of these anodes materials, towards the formation of metal sulfides and cerium oxysulfides in a dry atmosphere (Figure 8a) [26].

The formation of these sulfur compounds was corroborated by Raman and XPS spectroscopies. In contrast, when the sulfur test was carried out in the presence of $\mathrm{H}_{2} \mathrm{~S}$-containing humidified hydrogen (Figure $8 b$ ) no products for sulfidation were formed; only fluorite and metal phases were detected such in the reduced samples. It seems that depending on the $\mathrm{H}_{2} \mathrm{O} /$ fuel ratio and based on the reversal of reaction for cerium oxysulfide formation, under the employed humidified conditions $\mathrm{Ce}_{2} \mathrm{O}_{2} \mathrm{~S}_{\mathrm{x}}$ decomposes to regenerate cerium oxide phase.

To summarize, the successful doping of ceria with different cations has allowed to significantly improve the power densities, values of $400 \mathrm{~mW} \cdot \mathrm{cm}^{-2}$ in humidified $\mathrm{H}_{2}$ and $100 \mathrm{~mW} \cdot \mathrm{cm}^{-2}$ in methane-rich simulated biogas mixtures $\left(70 \% \mathrm{CH}_{4}\right)$ at $750{ }^{\circ} \mathrm{C}$ and $151 \mathrm{~mW} \cdot \mathrm{cm}^{-2}$ and 37 $\mathrm{mW} \cdot \mathrm{cm}^{-2}$ at $923 \mathrm{~K}$ have been achieved, respectively. Being these values within the best results reported for similar materials and operational conditions. Table 2 collects some of the most relevant reported data for their comparison.

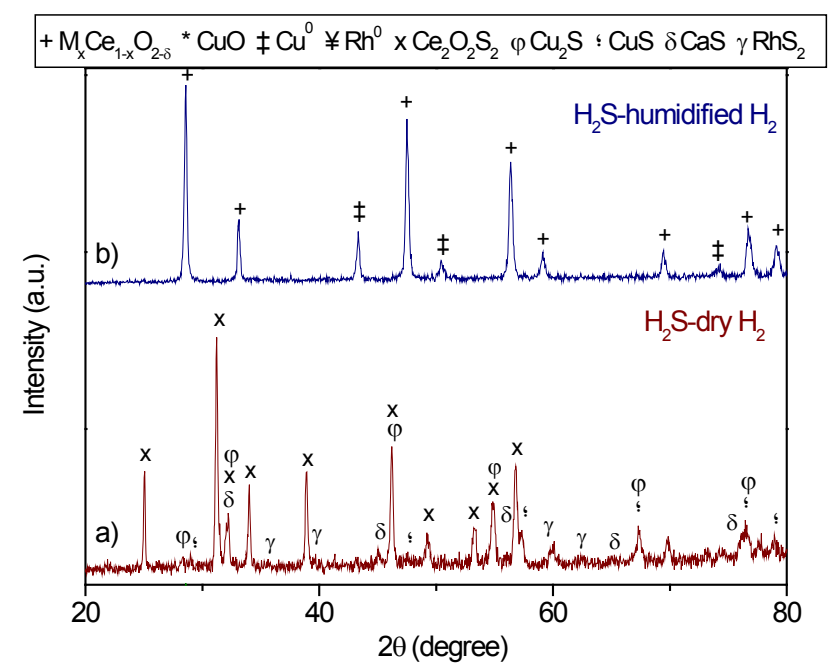

Figure 8. Sulfur tolerance tests of $\mathrm{Rh} / \mathrm{Cu}-\mathrm{CaCe}\left(500 \mathrm{ppm}-\mathrm{H}_{2} \mathrm{~S} / \mathrm{H}_{2}\right)$ : a) dry atmosphere; b) humidified atmosphere $\left(3 \% \mathrm{H}_{2} \mathrm{O}\right)$

Table 2. Reported data for single cell SOFCs with ceria-based anodes fed with hydrocarbon and $\mathrm{H}_{2} \mathrm{~S}$-containing fuels

\begin{tabular}{|c|c|c|c|c|c|c|}
\hline Anode & Electrolyte & Cathode & Fuel & $\begin{array}{c}\text { Temperature } \\
(\mathrm{K})\end{array}$ & $\begin{array}{c}\text { Maximum Power Density } \\
\left(\mathrm{W} \cdot \mathrm{cm}^{-2}\right)\end{array}$ & Ref. \\
\hline $\mathrm{Cu}$-ceria-LDC & LSGM & LSCF & $\mathrm{CH}_{4}$ & 1073 & 0.10 & {$[27]$} \\
\hline Cu-Ni-ceria-YSZ & YSZ $(60 \mu \mathrm{m})$ & LSM-YSZ & $\mathrm{CH}_{4}$ & 1073 & 0.30 & {$[28]$} \\
\hline $\mathrm{Cu}-\mathrm{Co}-$ ceria-YSZ & YSZ $(50 \mu \mathrm{m})$ & LSM-YSZ & $\mathrm{CH}_{4}$ & 1073 & 0.25 & [29] \\
\hline $\mathrm{Ni}-\mathrm{YSZ}+\mathrm{Ni} / \mathrm{Fe}-\mathrm{ZrO}_{2} / \mathrm{Cu}$ & YSZ & LSM & $\mathrm{CH}_{4} / \mathrm{O}_{2}$ & 1023 & 0.42 & {$[30]$} \\
\hline $\mathrm{Cu}$-ceria-YSZ & $\mathrm{YSZ}(60 \mu \mathrm{m})$ & LSM & $\mathrm{H}_{2} \mathrm{~S} / \mathrm{H}_{2}$ & 1073 & $0.31\left(50 \mathrm{ppm} \mathrm{H}_{2} \mathrm{~S}\right)^{*}$ & {$[31]$} \\
\hline NiCo-YSZ & YSZ $(500 \mu \mathrm{m})$ & LSM-YSZ & $\mathrm{H}_{2} \mathrm{~S} / \mathrm{CH}_{4}$ & 1123 & $94 \mathrm{~mA} \cdot \mathrm{cm}^{-2 \#}$ & {$[32]$} \\
\hline $\mathrm{NiCu}-\mathrm{GDC}+\mathrm{Ni}-\mathrm{LaAl}_{2} \mathrm{O}_{3}$ & $\operatorname{GDC}(630 \mu \mathrm{m})$ & LSCF & syngas & 973 & 0.04 & [33] \\
\hline Ni-GDC & GDC $(100 \mu \mathrm{m})$ & LSM & $\mathrm{CH}_{4} / \mathrm{CO}_{2}$ & 948 & 0.15 & [34] \\
\hline
\end{tabular}

* At 900 ppm $\mathrm{H}_{2} \mathrm{~S}$ performance drop precipitously.

\# It is not possible to calculate the maximum power density due to lack of information. 
The great variety of operational conditions (temperature, fuel composition, humidified or dry anode atmosphere, etc.), materials (cermet anodes, presence of catalyst interlayer, anode morphology, electrolyte thickness, etc.) and SOFC configurations (anode-supported or electrolyte-supported cells) studied for this purpose makes almost impossible a direct comparison of results. It should be noted that the best results are obtained at temperature higher than $1023 \mathrm{~K}$ and with a thin electrolyte $(\sim 50 \mu \mathrm{m})$ whereas in our configuration the electrolyte thickness is about $250 \mu \mathrm{m}$. In addition, although it is not shown in this table, long-term SOFC operation with methane fuel and/or $\mathrm{H}_{2} \mathrm{~S}$-containing fuels causes, in general, the formation of carbon deposits as well as sulfur poisoning, that dramatically worsen fuel cell performance.

\section{Conclusions}

Several co-doped ceria samples are successfully synthesized through the microemulsion coprecipitation method. The nanostructure material showed excellent chemical and thermal compatibility with common SOFC electrolytes as well as electrical behavior suitable for its use as anode for SOFC operating at a relatively low temperature.

Reliable and stable single cell performance was achieved over a long-term period in hydrogen, methane, biogas and hydrogen sulfide without evidence for the sulfur poisoning of anode material. In this way, although $\mathrm{H}_{2} \mathrm{~S}$ is commonly known as a poisonous gas for metallic-based catalysts, it has been found that the presence of appropriate $\mathrm{H}_{2} \mathrm{O}$ content minimizes the oxysulfide formation and improves the sulfur tolerance of $\mathrm{CeO}_{2}$-based catalysts.

The behavior of these ceria-based anodes under described conditions and its capability to operate in the presence of hydrogen sulfide (up to $500 \mathrm{ppm}$ ) offers great benefits in terms of energy and environmental management by eliminating the requirements for costly desulfurization units. It has been demonstrated that the selection of the appropriated dopant allows improving different properties of anode material in order to increase its fuel flexibility and poison tolerance. Nevertheless, complementary strategies could be additionally adopted in order to improve the cell performance and increase the reasonable power densities obtained. For example, the reduction of electrolyte thickness to values close to or even lower than $100 \mu \mathrm{m}$ is a crucial point for minimizing the internal cell resistances. Additionally, another interesting approach could be related to the anode microstructure, by increasing the active anode area that expands the interfacial contact area between the catalyst, the current collector and the fuel (TPB) and theoretically improves the cell performance. In both sense, at present, we are optimizing the tape-casting method for the preparation of thinner SOFC electrolytes as well as the controlled preparation method of nanostructured anodes that dramatically increase the active area.

\section{Acknowledgements}

Authors thank the Spanish Ministry of Economy and Competitiveness (MAT2013-45043-P) for financial support.

\section{REFERENCES}

[1] A. Atkinson, S. Barnett, R.J. Gorte, J.T.S. Irvine, A.J. McEvoy, M.B. Mogensen, S. Shingal, J.M. Vohs. Advanced anodes for high-temperature fuel cells, Nature Materials, Vol. 3, 17-27, 2004.

[2] E.P. Murray, T. Tsai, S.A. Barnett. A direct-methane fuel cell with a ceria-based anode, Nature, Vol. 400, 649-651, 1999.

[3] Fuel Cell Handbook, seventh ed., EG\&G Technical Services, Inc. for NETL of U.S. Dept. of Energy, 2004.

[4] S. Park, J.M. Vohs, R.J. Gorte. Direct oxidation of hydrocarbons in a solid-oxide fuel cell, Nature, Vol. 404, 265-267, 2000

[5] A. Martínez.Arias, A.B. Hungría, M. Fernández-García, A. Iglesias-Juez, J.C. Conesa, G.C. Mather, G. Munuera. Cerium-terbium mixed oxides as potential materials for anodes in solid oxide fuel cells, Journal of Power Sources, Vol. $151,43-51,2005$.

[6] A. Hornés, D. Gamarra, G. Munuera, A. Fuerte, R.X. Valenzuela, M.J. Escudero, L. Daza, J.C. Conesa, P. Bera, A. Martínez-Arias. Structural, catalytic/redox and electrical characterization of systems combining $\mathrm{Cu}-\mathrm{Ni}$ with $\mathrm{CeO}_{2}$ or $\mathrm{Ce}_{1-\mathrm{x}} \mathrm{M}_{\mathrm{x}} \mathrm{O}_{2-} \quad(\mathrm{M}=\mathrm{Gd}$ or $\mathrm{Tb})$ for direct methane oxidation, Journal of Power Sources, 2009, Vol. 192, 70-77.

[7] A. Fuerte, A. Hornés, P. Bera, A. Martínez-Arias, M. J. Escudero, L. Daza. Study of CuFe-Ce ${ }_{0.9} \mathrm{Gd}_{0.1} \mathrm{O}_{2-}$ as ITSOFC anode: Catalytic activity, thermal expansion, morphology, electrical conductivity and chemical compatibility, ECS Transactions, Vol. 25, 2183-2192, 2009.

[8] S. Ramesh, V. P. Kumar, P. Kistaiah, C. V. Reddy. Preparation, characterization and thermoelectrical properties of co-doped $\mathrm{Ce}_{0.8-\mathrm{x}} \mathrm{Sm}_{0.2} \mathrm{Ca}_{\mathrm{x}} \mathrm{O}_{2-}$ materials, Solid State Ionics, 181, 86-91, 2010 .

[9] Y. Qiu, J. Chen, J. Zhang. Effect of $\mathrm{CeO}_{2}$ and $\mathrm{CaO}$ promoters on ignition performance for partial oxidation of methane over $\mathrm{Ni} / \mathrm{MgO}-\mathrm{Al}_{2} \mathrm{O}_{3}$ catalyst, Journal of Natural Gas Chemistry, Vol. 16, 148-154, 2007.

[10] S. Banerjee, P. S. Devi. Understanding the effect of calcium on the properties of ceria prepared by a mixed fuel process, Solid State Ionics, Vol. 179, 661-669, 2008.

[11] M. F. Al-Kuhaili. Characterization of thin films produced by the thermal evaporation of silver oxide, Journal of Physics D: Applied Physics, Vol. 40, 2847-2853, 2007.

[12] A. Fuerte, R.X. Valenzuela, L. Daza. Preparation and characterization of SOFC anodic materials based on $\mathrm{Ce}-\mathrm{Cu}$, Journal of Power Sources, Vol. 169, 47-52, 2007. 
[13] S. Rossignol, F. Gerard, D. Mesnard, C. Kappenstein, D. Duprez. Structural changes of Ce-Pr-O oxides in hydrogen: a study by in situ X-ray diffraction and Raman spectroscopy, Journal of Material Chemistry, Vol. 13, 3017-3020, 2003.

[14] A. Hornés, D. Gamarra, G. Munuera, J.C. Conesa, A. Martínez-Arias. Catalytic properties of monometallic copper and bimetallic copper-nickel systems combined with ceria and $\mathrm{Ce}-\mathrm{X}(\mathrm{X}=\mathrm{Gd}, \mathrm{Tb})$ mixed oxides applicable as SOFC anodes for direct oxidation of methane, Journal of Power Sources, Vol. 169, 9-16, 2007.

[15] S. Lee, J.M. Vohs, R.J. Gorte. A study of SOFC anodes based on $\mathrm{Cu}-\mathrm{Ni}$ and $\mathrm{Cu}-\mathrm{Co}$ bimetallics in $\mathrm{CeO}_{2}-\mathrm{YSZ}$, Journal of Electrochemical Society, Vol. 151, A1319-A1323, 2004.

[16] A. Fuerte, R.X. Valenzuela, M.J. Escudero, L. Daza. Effect of cobalt incorporation in copper-ceria based anodes for hydrocarbon utilisation in Intermediate Temperature Solid Oxide Fuel Cells, Journal of Power Sources, Vol. 196, 4324-4331, 2011.

[17] A. Fuerte, R.X. Valenzuela, M.J. Escudero, L. Daza. Study of a SOFC with a bimetallic $\mathrm{Co} / \mathrm{Cu}-\mathrm{Ce}$ anode directly fuelled with simulated biogas mixtures, International Journal of Hydrogen Energy, Vol. 39 (8), 4060-4066, 2014.

[18] D. Pérez-Coll, D. Marrero-López, P. Núñez, S. Piñol, J.R. Frade. Grain boundary conductivity of $\mathrm{Ce} 0.8 \mathrm{Ln} 0.2 \mathrm{O} 2-\delta$ ceramics $(\mathrm{Ln}=\mathrm{Y}, \mathrm{La}, \mathrm{Gd}, \mathrm{Sm})$ with and without Co-doping, Electrochimica Acta, Vol. 51, 6463-6469, 2006.

[19] S. Banerjee, P. S. Devi. Understanding the effect of calcium on the properties of ceria prepared by a mixed fuel process, Solid State Ionics, Vol. 179, 661-669, 2008.

[20] LJ. Kundakovic, M. Flytzani-Stephanopoulos. $\mathrm{Cu}-$ and Ag-Modified Cerium Oxide Catalysts for Methane Oxidation, Journal of Catalysis, Vol. 179, 203-221, 1998.

[21] A. Cantos-Gómez, R. Ruiz-Bustos, J. vanDuijn. Ag as an Alternative for Ni in Direct Hydrocarbon SOFC Anodes, Fuel Cells, Vol. 11, 140-143, 2010.

[22] K. Sasaki, M. Muranaka, T. Terai. Compatibility analysis of $\mathrm{Ag}$ and electrolyte materials for LT-SOFCs and LT-SOECs, Solid State Ionics, Vol. 181, 1303-1307, 2010.

[23] A. Fuerte, R.X. Valenzuela, M.J. Escudero, L. Daza. Ag-Modified $\mathrm{Cu}$-Ceria anode for direct oxidation of hydrogen and methane fuels containing $\mathrm{H}_{2} \mathrm{~S}$, Proceedings of the Fuel Cell 2012: Science \& Technology-A Grove Fuel Cell Event. Berlin, Germany, 2012.

[24] A. Fuerte, M. J. Escudero. Electrochemical Impedance Study of $\mathrm{Ag} / \mathrm{Cu}-\mathrm{Ca}_{0.2} \mathrm{Ce}_{0.8} \mathrm{O}_{2+}$ Anode for SOFCs Operating with
Simulated Biogas, ECS Transactions, Vol. 68, 2805-2810, 2015.

[25] S. Wang, G.Q. Lu. A Comprehensive Study on Carbon Dioxide Reforming of Methane over $\mathrm{Ni} / \gamma-\mathrm{Al}_{2} \mathrm{O}_{3}$ Catalysts, Industrial Engineering Chemistry Research, Vol. 36, 2615-2625, 1999.

[26] A. Fuerte, R.X. Valenzuela, M.J. Escudero, L. Daza. Minimising the Sulfur Interactions with a SOFC Anode based on $\mathrm{Cu}-\mathrm{Ca}$ Doped Ceria, Proceedings of $10^{\text {th }}$ European SOFC Forum, Chapter 18, 25-34, 2012. Lucerne, Switzerland.

[27] Z.H. Bi, J.H. Zhu. A Cu- $\mathrm{CeO}_{2}-\mathrm{LDC}$ Composite Anode for LSGM Electrolyte-Supported Solid Oxide Fuel Cells, Electrochemical and Solid-State Letters, Vol. 12, B107-B111, 2009.

[28] H. Kim, C. Lu, W.L. Worrel, J.M. Vosh, R.J. Gorte. Cu-Ni Cermet Anodes for Direct Oxidation of Methane in Solid-Oxide Fuel Cells, Journal of Electrochemical Society, Vol. 149, A470-A476, 2002.

[29] S.I. Lee, K. Ahn, J.M. Vohs, J.R. Gorte. Cu-Co Bimetallic Anodes for Direct Utilization of Methane in SOFCs, Electrochemical and Solid-State Letters, Vol. 8, A48-A51, 2005.

[30] W. Wang, H. Zhu, G. Yang, H.J. Park, D.W. Jung, C. Kwak, Z. Shao. A NiFeCu alloy anode catalyst for direct-methane solid oxide fuel cells, Journal of Power Sources, Vol. 258, 134-141 (2014).

[31] H. He, R.J. Gorte, J.M. Vohs. Highly Sulfur Tolerant Cu-Ceria Anodes for SOFCs, Electrochemical Solid-State Letters, Vol. 8, A279-A280, 2005.

[32] C.M. Grgicak, M.M. Pakulska, J.S. O'Brien, J.B. Giorgi. Synergistic effects of $\mathrm{Ni}_{1-\mathrm{x}} \mathrm{Co}_{\mathrm{x}}-\mathrm{YSZ}$ and $\mathrm{Ni}_{1-\mathrm{x}} \mathrm{Cu}_{\mathrm{x}}-\mathrm{YSZ}$ alloyed cermet SOFC anodes for oxidation of hydrogen and methane fuels containing $\mathrm{H}_{2} \mathrm{~S}$, Journal of Power Sources, Vol. 183, 26-33, 2008.

[33] M. Miyake, M. Iwami, K. Goto, K. Iwamoto, K. Morimoto, M. Shiraishi, K. Takatori, M. Takeuchi, S. Nishimoto, Y. Kameshima. Intermediate-temperature solid oxide fuel cell employing reformed effective biogas: Power generation and inhibition of carbon deposition, Journal of Power Sources, Vol. 340, 319-324, 2017.

[34] T. Papadam, G. Goula, I.V. Yentekakis. Long-term operation stability tests of intermediate and high temperature Ni-based anodes' SOFCs directly fueled with simulated biogas mixtures, International Journal of Hydrogen Energy, Vol. 37, 16680-16685, 2012. 